countries threatened with sanctions, partly because of an agreement in which both countries promised to protect intellectual property rights while addressing the health issues.

It is not clear how South Africa could bring its legislation in line with its government's commitment to TRIPs. But Alec Erwin, the country's minister for Trade and Industry, maintains that South Africa has sought no agreement with the US on patent right exhaustion.

This occurs when the patent holder loses control over the further sale of his products, and - unlike parallel importing - is not prohibited by TRIPs. In terms of the treaty, compulsory licensing is permitted at the discretion of individual countries.

Local firms could then be licensed to manufacture goods using another company's patented formula, provided that the patent owner is compensated and the government's action is subject to judicial review. This provision had previously been opposed by the US government, which has reserved the right to pressure countries not to use it.

South Africa has not withdrawn its intention to use parallel imports or compulsory licensing to obtain drugs at lower prices, nor did the US government sanction these practices. But parallel importing remains a likely subject of proposed reform of the South African Medicines and Related Substances

Act. Meredith Wadman \& Michael Cherry

\title{
AAAS to honour 'persecuted' Ukrainian marine biologist
}

\section{London}

Sergei Piontkovski, the Ukrainian marine biologist facing criminal charges over his role in various international research projects, is to be honoured at a reception held annually by the American Association for the Advancement of Science (AAAS) to recognize persecuted scientists.

Piontkovski and colleagues at the Institute of Biology of the Southern Seas in Sebastopol have been under close scrutiny from the local branch of the country's security services - formerly the KGB — since the end of October over their links with the West (see Nature 401, $835 \& 402,6 ; 1999$ ).

The AAAS's Science and Human Rights Program will host the reception at the association's annual conference in Washington next February. In a letter to Piontkovski, Elisa Muñoz of the AAAS says that "the Program will honor you in recognition of the persecution that you have endured". She adds that AAAS officials "have been following your case and will continue to monitor events with concern".

Initially, Piontkovski faced charges related to espionage and hard currency concerning a number of international science grants. However, he has now been charged with illegal currency operations and organized crime in relation to his handling of project funds paid to him in hard currency. Piontkovski expects court proceedings to start soon, and the case might start in January.

INTAS, the European body that promotes cooperation with scientists from the former Soviet Union, is one of the agencies making payments to Piontkovski, on a project on plankton distribution jointly funded by the Ukrainian Ministry of Science.

INTAS secretary David Gould said last week, "We have agreements of scientific cooperation which clearly state the terms of the contract".

Such terms include the conditions under which payment can be made, and foresee payment in hard currency. INTAS says that, as far as it is aware, currency has been handled in accordance with signed agreements.

INTAS is due to hold a meeting in midJanuary to evaluate bids from newly emerging states for the 1999 funding call. "Clearly, if this is not resolved there could be consequences for the support of projects in Ukraine," says Gould. INTAS says it is continuing its "dialogue" with the science ministry.

Ukraine's president, Leonid Kuchma, has been reported as seeking a sign that Ukraine might achieve membership of the European Union. One union official says that, given the current situation in Ukraine, it will get a "negative response".

Natasha Loder

\section{Berlin places genomics among top funding priorities}

Munich

Research in Berlin that is supported by the German capital is to be focused on twelve areas — including genomics. The areas have been identified by an expert panel as reflecting the city's scientific strengths.

Ingolf Hertel, the state secretary for research in the Berlin ministry of science, has also announced plans to increase competition for funds between universities and research institutes. A small percentage of the DM3.5 billion (US $\$ 1.8$ billion) annual budget for institutional funding of science and education will be distributed competitively.

Both moves are intended to improve the quality of publicly funded research and the effectiveness with which research funds are used. Priority areas include molecular medicine and genome research, information technology, transport research, material research, optics, Earth sciences, applied mathematics and social studies.

The topics were selected by the so-called strategy forum on science, research and

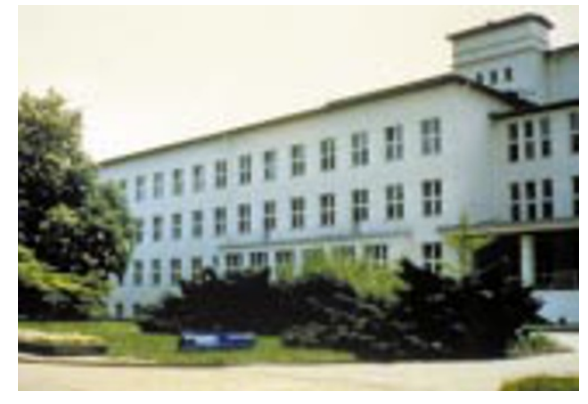

Hotspot: a laboratory building of the Max Delbrück Centre for Molecular Medicine.

innovation. This was set up in January by university presidents, science ministry officials and representatives from industry and from the large science and technology centres Buch and Adlershof.

Since reunification, Berlin has become one of Germany's scientific hotspots, and now hosts three universities and 38 research institutes. But the science budget of the formerly isolated - and heavily subsidized - city has fallen by several hundred million Deutschmarks since 1990 as subsidies from the federal government have been cut.

"Re-modelling Berlin's scientific landscape under constant budgetary constraints was, and is, a notoriously hard job," says Hertel. "Streamlining research and enlarging technology foresight will therefore be major political priorities in the next years."

But he adds that the ministry has no desire to dictate the kind of research scientists should do. "The new funding concept will be worked out jointly with the scientific community," he says.

Hans Lehrach, director of the Berlinbased Max Planck Institute for Molecular Genetics, hopes the new scheme will boost genome research in Berlin. Together with other leading genomics researchers, Lehrach has drafted a proposal for an interdisciplinary genome research centre that would bring together the various aspects of genome research carried out in Berlin. Quirin Schiermeier 